\title{
THE TRUSTEE'S OBLIGATION TO INFORM THE PRINCIPAL ON THE PROGRESS OF THE MANDATE. THE ACCOUNTING MANAGEMENT AND THE REPORT
}

\author{
Dana TULAI ${ }^{1}$ \\ 1 Political Economy Department, Faculty of Economical Sciences and Business \\ Administration, Babeș-Bolyai University, Cluj-Napoca, România \\ dana.tulai@econ.ubbcluj.ro
}

\begin{abstract}
This paper aims to bring to attention an issue which involves both economical and juridical aspects: agents' obligation to give an account to principals, derived from mandate contracts. The legal doctrine, both Romanian and European, has largely debated upon this aspect, particularly the form in which the accounting report must be given, as well as the possibility of tacit extempt from the obligation of the trustee to hand over the management account, in cases in which the contractual relations of the parties are based upon a high degree of trust. As shown in this paper, we believe that a genuine accounting report is required from agents only if the principals explicitly demand it. Also, since the legal provisions on the matter do not expressly impose any formalities for the completion of this report, we believe that it is the principals' decision to establish the form in which the trustees must hand over the accounts.
\end{abstract}

Keywords: mandate; accounting; report; management

JEL Classification: $K 11 ; K 12 ; K 15 ; K 22$

As it appears from the legal regulations in force, in a mandate contract, the agent's obligation to "give an account" to the principal is a complex one, since it involves various duties. First of all, the trustee must inform the principal about the execution of his mission and to present a report to him. Secondly, he is legally bound to hand over to the principal all that he has received by virtue of the mandate and pay him interest for the sums owed to the principal. Finally, the agent must prove his loyalty to the principal, as well as show the diligence with which he takes care of his interests, by taking all the necessary measures to preserve the assets held for the principal.

Therefore, first of all, the agent's accounting obligation has a legal aspect, embodied in his duty to inform the principal about the execution of the mandate, referred to as the "reporting obligation". Since the trustee concludes legal acts on behalf of the principal, it is only fair that he keeps the principal up to date with the completion of the duties entrusted to him. The old Romanian Civil Code (art. 382) regulated this duty in a distinct and explicit manner. According to the new Civil Code, it derives from the general obligation to give an account.

Secondly, the agent's duty also has an accounting aspect: the trustee must provide the principal with an account of his management. As the legal doctrine has showed, this obligation "is not subject to any particular formal requirements, but still, it is not a mere arithmetic framework; it is a contract subject to the common law in question. It must include both assets and liabilities." (Dutilleul, Delebecque, 1998: 493). An author (Dănișor, 2006) stated that the principal may exempt the 
agent for the use of the legal forms in giving accounts; however, the law does not establish any special formal conditions for the agent's management report.

Therefore, the trustee's duty to be accountable to the principal primarily involves the obligation to inform him about the performance of the task entrusted to the agent.

The principal is entitled at any time during the term of office to know the status of the operations with which he has empowered the agent, as well as the accounting situation arising therefrom. Therefore, we believe that the trustee will have to justify the management whenever the principal so requests, not only at the end of his term of office.

The doctrine has considered that the principal who has dismissed his agent, without having received the management report, can no longer request it, as it is presumed that he has appropriated the statements of the trustee (BaudryLacantinerie, Wahl, 1907: 359). In the light of the regulations contained by art. 2037 of the new Romanian Civil Code ("Upon termination of the mandate by any means, the agent is bound to complete his obligations provided by art. 2019 and 2020"; art. 2019 regulates the duty to give account, whereas art. 2020 states that the agent must pay interest for the amounts owed to the principal), we believe that the duty to report and implicitly the principal's correspondent right to require the handing over of the accounts subsists even after the termination of the mandate, however it might have occurred.

In order to evade his obligation of accountability, the agent cannot rely on the fact that he acted in reality as a prête-nom representative for a third party, unless the principal himself knew and accepted this situation.

The agent must justify his conduct and inform the principal about the status of the operations with which he was enstrusted.

The legal doctrine (Dutilleul, Delebecque, 1998: 492) pointed out the difference between this obligation to inform that the trustee has towards the principal and the duty of advice, that jurisprudence sometimes assigns to the agent, especially the professional one, such as the real estate agent or the legal adviser. The obligation to inform is a direct and necessary consequence of the intuitu personae character of the mandate contract, and therefore it is a duty of all agents; the obligation to advise, on the other hand, is determined by the proffesional nature of certain mandates. For example, the lawyer "shall explain to his client the circumstances of the case, the current situation, possible future developments and results, in a reasonable manner, according to the specific circumstances of the case" (art. 140 paragraph 2 of the Decision of the Council of the National Union of the Romanian Bar-Associations no. 64/2011 for the coming into force of the Status of the Lawyer Profession).

But what exactly does the agent's obligation to inform involve? It comes in the form of a report on the development of the trustee's mission, indicating both the difficulties and its results. This duty of the agent can undoubtedly be qualified as a result obligation.

Therefore, the agent is bound to inform the principal of the diligences submitted for the execution of the mandate; the mere completion of the mandate is not sufficient, as it must also be communicated to the principal, this obligation to inform being accesory to the duty to carry out the mandate in a diligent manner.

The obligation to give an account is not a purely accounting one. It not only requires the trustee to be held responsable for what he has received and what he 
has given upon the execution of his mandate, but it also involves the completion of a report on the measures taken to carry out the contract (Pétel, 1988: 367-440). Jurisprudence has established that exceptionally, in situations in which the specific relations between the contracting parties implies a very high degree of trust (the typical case being that of family relations), the possibility of tacit exemption of the trustee from the obligation to give an account may be accepted (Cass. civ., the $16^{\text {th }}$ of March 1892, D.P. 1892; Cass. 1re civ., the $7^{\text {th }}$ of January 1982, D. 1982).

The handing over of the account normally happens at the end of the contract, but the particularities of the mission entrusted to the agent may also require a presentation of the report during the execution of the mandate, so that the principal is kept up to date with the progress of the operations and that he could, if necessary, act himself for the successful completion of the business (obligation which also arises from the provisions of art. 2018 paragraph 2 of the Civil Code).

In a 2006 ruling of the French case-law (C. Ap. Aix-en-Provence, 1re ch., sect. A, the $7^{\text {th }}$ of March 2006), the Aix Court stated that, in the case of any mandate in common interest, the agent must regularly inform the principal of the preceedings undertaken, under the penalty that the principal, deprived of information, may revoke the mandate conferred. In this particular case, a woman died, leaving her inheritance to her three children and her husband. The husband received a mandate from the sons to make all the necessary steps on their behalf in order to obtain permission to devide a piece of land that was part of the succession and to carry out its division. A subdivision permit was issued, subject to the commencement of the works within 18 months of notification, under penalty of expiry of the permit. Two of the sons rewoked the mandate shortly before 18 months after receiving the permit. The father and the other son claim that the term of office has been revoked in an abusive manner, and that an appropriate compensation should be granted, corresponding to the value that would have been gained by the division of the land into lots. The Court pointed out that the power of attorney entrusted by several co-owners to one of them, in order to carry out an operation on a plot of land part of the succession, constitutes a mandate in common interest. In the absence of mutual consent of the parties, such a mandate may only be revoked for a legitimate cause recognized in court, such as the fault of the agent.

However, the agent did not inform the principals of the measures taken after the authorization was issued. Furthermore, he cannot show that, at the time of the revocation of the mandate, the works had begun, nor that he had concluded a contract with an undertaker to start them before the expiry of the permit. Therefore, the negligence of the trustee justifies the revocation of the mandate and excludes his right to compensation. Going even further, it can be said that a mandate in common interest, even if correctly carried out, may be legitimately revoked by the principal on the grounds that he has not been informed by the agent of the diligences undertaken and he has not been aware of them from elsewhere.

The duty to give an account obliges the agent to also keep the accounts for the operations carried out and to return the ammounts received from third parties, otherwise making himself liable even to a criminal sanction. For example, art. 243 of the Penal Code sanctions "the misappropriation of another's movable property, [...], or the non-delivery within 10 days from the moment he learned that the property did not belong to him." Art. 242 also criminalizes fraudulent management, 
consisting in "causing damage to a person, on the occasion of the administration or preservation of their assets, by the one who does or must take care of the administration or preservation of such assets." In a court case from 1985 (Cass. crim., the $12^{\text {th }}$ of November 1985), the administrator of a condominium received premiums from certain companies entrusted with the maintenance of the estate; because he did not include these ammounts in the accounts he gave to the coowners, he was convicted of breach of trust.

An important issue that had to be resolved by the courts was to decide whether the trustee's creditors could pursue his professional accounts.

The French courts (Cass. 1re civ., the $20^{\text {th }}$ of April 1983) have ruled that if the sums received from third parties have been placed into an ordinary account, they are part of the trustee's assets and therefore they are likely to be pursued by his personal creditors. The respective amounts, regardless of their origin, as long as a specially-designated account (or sub-account) was not set up for them, in order to allow their individualization, they could not be separated from the patrimony and the "bankruptcy" of the agent. However, if the amounts have been transferred to a special account, they are individualized and do not belong to the trustee, but to the principal, and can only be claimed by the creditors of the latter.

Of course, everything that the trustee receives for the principal enters directly into the principal's patrimony, the agent having only the quality of a holder of those assets; therefore, not being part of his patrimony, these ammounts cannot be pursued by his creditors; it is true, on the other hand, that if the sums received for the principal do not enter into a separate account, they cannot be differentiated from the other sums belonging to the agent, therefore the personal creditors of the trustee, having a right of general pledge over all his patrimonial assets, could pursue these ammounts. Therefore, the problem is to be able to individualize the goods belonging to the principal, as long as they are in the custody of the agent. Here, however, comes the obligation of the trustee to keep accounts of the operations carried out in the execution of the mandate, which also involves the opening of a special account for these amounts.

Thus, some professionals are required to keep separate accounts, such as lawyers, notaries, administrators of co-owners' associations. The file must be sent to the successor to the person in charge of the business. For example, jointlyowned property managers must open a separate account for each co-ownership association they manage, so that, in absence of the principals' agreement, the accounts cannot merge for debt settllement; this ensures the protection of the funds of each principal against the others' creditors, as well as against the agent's creditors.

In the case of the lawyer, the Council of the National Union of Romanian BarAssociations has established strict rules in this regard, in order to avoid the possibility of confusion of the assets held by the lawyer for his clients, either among each other, or between them and the lawyer's personal assets. This also diminishes the risk for the lawyer to use the assets of his clients for his personal benefit.

A matter of doctrinal discussion is the form in which this report must be delivered.

The French doctrine has stated that the trustee should be required to provide the principal with a true accounting, in accordance with the rules of the common law on the matter, and that the principal could demand his agent to provide detailed records of receipts and expenditure. It is therefore a question of keeping regular 
accounts, as it is not sufficient for the trustee to state as a whole what he has received and what he has spent, since that would only have the value of a statement and not that of an account. The trustee will be required to keep a management account, as well as send the principal the balance sheet periodically or at least at the end of his term of office. The agent will have to keep records and justify every single collection and expenditure made on behalf of the principal.

The French doctrine (Baudry-Lacantinerie, Wahl, 1907: 360) has shown that the agent will have to mention in the account both the receipts and the expenses, accompanied by supporting documents, which are necessary for the principal to be able to check the truthfulness of his statements. Also, if the agent is a trade professional, the principal may ask him to present the records; he may claim this even if the agent does not have the above-mentioned quality, if he has kept accounting records.

In the assets column, the agent must mention first of all the necessary advances and expenses that he has made in order to execute the mandate, according to art. 2025 paragraph 2 of the Civil Code: "The principal shall reimburse to the agent the reasonable expenses advanced by the latter for the completion of the mandate, together with the appropriate legal interests, calculated from the date when those expenses were made." Therefore, the assets will also include the interests on the amounts that the agent paid as an advance from the day that these expenses were made, as well as the fees, if applicable, according to art. 2027 of the Civil Code: "If the mandate is executed for a fee, the principal is obliged to pay the trustee the remuneration, even if, through no fault of the agent, the mandate could not be executed."

In the liabilities column, the agent must write all that he has received as such, regardless of whether what he has received was not actually due to the principal; this is normal, if we consider that the trustee received those goods for the principal, and not for himself. If those amounts or other received goods are not rightfully owed to the principal, the injured third parties will act against the principal for the refund of the undue payment and not against the trustee.

An author of the classical French legal doctrine (Laurent, 1887: 553) stated that the principal could not exempt the agent from the duty to give account, as this would be the very essence, not only the nature of the mandate: the obligation to manage the principal's affairs cannot exist without the duty to hand over the report of the management. Moreover, keeping the accounts would be the basis of the principal's claim against the agent, concerning the non-execution of the mandate or his fault committed in the performance of the tasks received. Therefore, to exempt the trustee from accountability to the principal implies to exonerate him from any liability, including fraud or gross negligence; such an agreement of the parties would be absolutely null and void, since it would violate public order and morals. However, according to the quoted author, the clause by which the trustee is exempted from liability could be valid, if the intention of the parties was not to conclude a mandate (which is a contract for the benefit of the principal -the free mandate- or of both contracting parties -the remunerated mandate-), but a liberality in the form of a mandate. The case-law has admitted exemptions from the obligation established by art. 1993 of the French Civil Code (art. 2019 of the Romanian Civil Code), justified by the intention of the contracting parties.

Thus, it mentions the case of a farmer from Santo Domingo who, having been in France for a long period of time, entrusted his father with a mandate empowering 
him to exploit the principal's agricultural estate, including selling or alienating any goods or civil fruits belonging to him, as if he were the owner of those assets, without being bound to any obligation to give an account. After the death of both contracting parties, the heirs of the principal requested from the heir of the trustee a report of management of the estatte, which the court of first instance also ordered. However, the Court of Appeal considered that the express waiver clause of the agent regarding the obligation to give an account was valid, taking into account the particular circumstances of the case: it was the intention of the wealthy son to make a donation for his poor father, which would provide him with the financial means to survive, by granting him the right to manage the farm without the obligation to hand over the management account. Therefore, the contract was declared valid, not as a mandate, but as a disguised donation, the jurisprudence admitting the validity of certain liberalities made in form of onerous acts.

In another case, the court stated that, as a general rule, all agents are bound to hand over the management account to the principal, but in order for this rule to apply, first of all, one must talk about a genuine mandate, not a liberal act disguised as a mandate, and secondly, the agent must have possessed those elements necessary for the execution of his mandate, which are needed to write and justify the management report.

As far as we are concerned, we are in favor of another approach of the French doctrine on the matter, which considers that the mandate is a contract essentially based on trust, therefore the obligation to give an account only characterizes its nature, without being essential (unlike the case of legal guardianship, for example, where the account due by the guardian is the essence of this institution); therefore, the principal may relieve the agent completely of this obligation, if the nature of the relationship between the parties implies such a degree of trust.

Both Romanian (Safta-Romano, 1999: 243) and French doctrine sugest the idea that, being in fact a matter of an act free of charge, the principal must have legal capacity to make the liberality, and the trustee to receive it. Attention was also drawn to the fact that some trustees cannot be relieved of this obligation to be held accountable, precisely the professional agents.

Therefore, we consider that a genuine account will have to be kept by the trustee only if the principal expressly requests so; since the law does not explicitly impose any form of this management, it is up to the principal to decide the form in which the accounts of the mandate will have to be highlighted and handed over.

This opinion has also been shared by courts repeatedly.

Thus, a decision of the French Court of Cassation (Cass. 1re civ., the $18^{\text {th }}$ of January 1989) established that it complied with the requirements of the Civil Code concerning the agents' report of accounting, "a private signature act by which the principals acknowledge that they have received in full amount the sums derived from the sale made the same day, for which they had given a mandate, and therefore give full discharge to their trustee."

Moreover, the French Court of Cassation (Cass. 1re civ., the $12^{\text {th }}$ of November 1957) ruled that the trustee's exemption from the obligation to hand over the accounts could be given by the principal even tacitly, as a result of the special nature of the parties' relations or other circumstances, which would make it 
impossible or unnecessary to perform this obligation. For example, handing over the management account is unnecessary when the principal exercises constant control over the agent, in which case the accounts are being presented to the principal as the trustee performs the operations undertaken. In one case, French case-law stated that a notary's assistant is not required to disclose to the notary the account of the transactions which he has carried out in pursuance of his immediate orders. This ruling is debatable: indeed, the obligation to hand over the account does not operate in this case, by virtue of the fact that it is difficult to identify the assistant as a trustee, since he has rather the position of an employee. For the same reason, jurisprudence has sometimes ruled that there is no obligation to hand over the accounts in the case of sons who act as trustees for their parents (Cass., the $12^{\text {th }}$ of January 1830), or in the case of the wife acting as trusttee of her spouse (Orléans, the $5^{\text {th }}$ of January 1859), in respect of those operations which the principals used to entrust to the respective agents. However, in all these cases, it was stated that these persons had the obligation to keep accounts of the acts concluded on behalf of their principals beyond the limits of their usual duties.

We believe that, despite the existence of close family relations between these contractors, the presence of an obligation to report cannot be excluded. It is true that in practice such a duty is rarely agreed upon by close relatives, the mandate being given to them precisely because of the trust they inspire, but this does not mean that its existence must be ruled out from the start. Even if the obligation had not been verbally agreed, the presumption of such a tacit agreement between the parties could derive from the specific circumstances of the case. We feel that moral rather than legal considerations made the judges dismiss this presumption: it is indeed uncomfortable to identify a son as his mother's agent or a wife being in the position to present her husband with an accounting report. However, such an obligation is not inconceivable, especially under the provisions of the new Civil Code, which regulates the relations between spouses in a much more pragmatic manner, no longer starting on the presumption that there is always complete mutual trust between spouses, as the old Civil Code did. Presently, since there is the possibility for the spouses to choose the separation of patrimonies, it is not unimaginable that they would expect an accounting report in case of a management mandate.

Nevertheless, the issue of the existence of a tacit relief by which the trustee is exempted from the obligation to give an account must be looked upon in a particular manner if the spouses opt for the legal or conventional community of property regime, due to the special nature of the principal-agent relationship.

In case of the legal community of property, the spouses voluntarily agree with a legal framework which is extremely permissive in relation to the freedom that they have in managing jointly-owned goods. Thus, under the presumption of a mutual mandate of representation, any of the co-owners has the right to use the jointlyowned property by himself, without the express consent of the other, with the only limitation of not changing its destination. Also, each spouse has the right to conclude acts of preservation or administration of the jointly-owned property by himself, as well as to acquire such goods. To the extent that his interests in the community of property have been harmed, the spouse who has not participated in the completion of those acts may only claim damages from the other, without causing prejudice to the rights of bona fide third parties. Moreover, any of the 
spouses may dispose by himself of the movable property for which the law does not require specific publicity formalities. Under these legal regulations, which provide for a very permissive regime and for extended rights of the spouses in managing and even alienating certain jointly-owned assets, it is obvious that any of the spouses may exempt the other, even tacitly, from any duty of report; however, the Civil Code (art. 345 paragraph 4) explicitly regulates the right that the injured spouse has to claim damages, if his patrimonial interests were harmed. Still, this does not imply that it is inconcievable for the spouses not to have waived the obligation to report, but only that the court must take into consideration the nature of the contracting parties relation when assessing the probability of a tacit dispensation.

As regards the situation of the conventional community of property, the presumption that there is a tacit exemption between spouses regardind the holding and delivery of accounts will be assessed according to the intention of the spouses when they opted for this marital regime. If the spouses wanted to put even more trust and freedom into their patrimonial relations, by including personal assets and debts in the community, then it is very likely that there is a tacit exemption from accounting or handing over a report. However, if, on the contrary, the spouses' intention was to restrict the specific freedoms of the legal community of property, then the court will have to assess more reluctantly the possibility of a tacit waiver of the right to claim a report on the management of jointly-owned property.

The agent is held accountable to the principal, as well as to his successors or representatives. Art. 2037 of the Civil Code establishes the existence of certain obligations of the agent even after the termination of the mandate in any way, such as the duty to hand over the accounts of the mandate and to pay the interests due for the amounts he used for his personal benefit or with which he remained indebted towards the principal; these duties will be performed towards the successors/representatives of the principal. Moreover, art. 2030 of the Civil Code stipulates that, if the mandate implies the conclusion of successive acts within an activity that is continuous and in progress, it will continue, despite the occurrence of a cause for termination, except for the situation in which the contracting parties or their successors want to revoke it.

It is possible that the person who gave the mandate does not have any qualifications to receive the handover of the management accounts. For example, if the legal representative of an incapacitated individual gave the mandate and that person has regained legal capacity in the meantime, the report will have to be handed over to the person on whose behalf the mandate was given. The legal doctrine (Laurent, 1887: 575) has discussed an interesting issue, related to the situation in which the mandate was given by the apparent heir, who was later removed from the succession by means of a petition for inheritance, before the accounts of the mandate were handed over; it is obvious that the report will not be handed over to the apparent heir, who has lost their quality in relation to the succession, by virtue of which he had conferred the mandate; the trustee actually worked for the real heir, to whom he will therefore have to hand over the management account. 


\section{References:}

1. Baudry-Lacantinerie, G., Wahl, A. (1907) Traité théorique et pratique de droit civil, tome 24, Des contrats aléatoires. Du mandat, du cautionnement, de la transaction, 3ième èd., Librairie S.R.S.J.P., Paris, pp. 359-360

2. Dănișor, D. C. (2006) Considerații privind contractul de mandat: accepțiuni și evoluții ale termenului în drept, Revista de științe juridice 2/2006

3. Dutilleul, F. C., Delebecque, Ph. (1998) Contrats civils et commerciaux, 4e ed., Dalloz, Paris, pp. 492-493

4. Laurent, F. (1887) Principes de droit civil français, tome XXVII, Librairie A. Marescq, Paris, pp. 553-575

5. Pétel, Ph. (1988) Les obligations du mandataire, Litec, pp. 367-440

6. Safta-Romano, E. (1999) Contracte civile. Încheiere. Executare. Încetare, Ed. Polirom, lași, pp. 243 